\title{
The importance of creating multimedial electronic learning resources
}

\author{
Aziza JURAEVA ${ }^{1}$ Shoira NOSIROVA ${ }^{2}$ \\ Navoi State Pedagogical Institute
}

\begin{tabular}{l} 
ARTICLE INFO \\
\hline Article history: \\
Received August 2021 \\
Received in revised form \\
20 August 2021 \\
Accepted 15 September 2021 \\
Available online \\
11 October 2021 \\
\hline
\end{tabular}

Keywords:

information, technology, education, system, interactive, presentation, digital, resource.

\section{ABSTRACT}

The article covers the issues of informatization of education in an informed society, the role of ICT and educational resources in the modern educational system, the essence, classification of e-learning resources, the model composition of e-learning resources, the requirements for their creation, the principles and stages of creation.

2181-1415/C) 2021 in Science LLC.

This is an open access article under the Attribution 4.0 International (CC BY 4.0) license (https://creativecommons.org/licenses/by/4.0/deed.ru)

\section{Мултимедиали електрон таълим ресурсларини яратишнинг ахамияти}

\section{Калит сўзлар:}

ахборот, технология,

таълим, тизим, интерфаол, тақдимот, рақамли, ресурс.

\begin{abstract}
АННОТАЦИЯ
Мақолада ахборотлашган жамиятда таълимни ахборотлаштириш масалалари, замонавий таълим тизимида АКТ ва таълим ресурсларининг ўрни, электрон таълим ресурсларининг мохияти, таснифи, электрон ўқув ресурсларининг намунавий таркиби, уларни яратишга қўйилган талаблар, яратиш тамойиллари ва босқичлари ёритилган.
\end{abstract}

\footnotetext{
${ }^{1}$ Lecturer, Department of Informatics, Navoi State Pedagogical Institute, Navoi, Uzbekistan

2 Doctor of Technical Sciences, Associate Professor, Department of Informatics, Navoi State Pedagogical Institute, Navoi, Uzbekistan
} 


\section{Важность создания мультимедийных электронных учебных ресурсов}

\author{
Ключевые слова: \\ информация, технология, \\ образование, система, \\ интерактивная, \\ презентация, цифровой, \\ ресурс.
}

\begin{abstract}
АННОТАЦИЯ
В статье рассматриваются вопросы информатизации образования в информированном обществе, роль ИКТ и образовательных ресурсов в современной образовательной системе, сущность, классификация электронных образовательных ресурсов, типовой состав электронных образовательных ресурсов, требования к их созданию, принципы и этапы создания.
\end{abstract}

Globally, humanity has stepped into a common historical process called globalization and informatization. The penetration of information technology in the fields of science, education, production opens a wide range of information resources for every citizen and requires a high level of service to them. UNESCO acknowledges that the introduction of digital technologies into the education system creates a new environment for communication, in which the student learns not only the skills of working with digital technologies, "Simple abilities" - information retrieval and integrated perception of information, positive and critical assessment of information, teamwork. performance and skills such as creative, logical thinking [1].

The basis of a modern education system is a high-quality and high-tech environment. Its creation and development is technically complex, but such an environment serves to improve the education system, the introduction of information and communication technologies in education.

Adapting the education system to the digital generation through the development and effective use of innovative educational technologies, multimedia electronic resources and didactic models in the learning process, as well as using computers, laptops, tablets, tablets, smartphones and any other latest devices, anytime, anywhere providing access to education for everyone from any teacher.

Multimedia technology transmits information to a person at the same time intelligible, many forms (including speech, painting, drawing, imagery, music, numbers and letters). This is technology information retrieval, copying, and displaying on another computer in the form, can transfer and any combination of them can create[3].

It is expedient to ensure a strong integration of modern information and communication technologies and educational technologies, to create additional conditions for the continuous development of professional skills of teachers, to organize and conduct training courses for teachers on the following topics:

- development of interactive and multimedia presentations related to the Internet for lectures and seminars and the use of interactive presentation systems;

- implementation of distance learning process using real-time interactive presentation systems, video conferencing systems, virtual halls;

- use of cloud technologies, virtual reality, augmented reality;

- use of 3D printers in the development of digital didactics, digital educational models, didactic materials, experimental designs;

- Develop a scientific website for teachers and students to discuss projects, dissertations, research papers, and more.

Because multimedia applications are able to express information in multiple views, the learning process can be organized more efficiently. possible. This can save up to $30 \%$ of the time spent learning 
a particular learning material, and the knowledge gained will be stored in memory for a longer period of time than other information.

When using multimedia technologies in the lessons, the structure of the lessons almost does not change, that is, the planned stages for the lesson are preserved, only their time characteristics change. It should be noted that in this case the motivation is enhanced and focused on cognition. This increases the effectiveness of education, as it is practically impossible to organize students 'creative activities by not being interested in replenishing the knowledge base, not being able to imagine, and not trying to know emotionally[4].

Organizing multimedia presentations through hyperlinks develops systematic and analytical thinking. In addition, with the help of presentations it is possible to organize cognitive activities in different forms. The use of computer-information technology model, depending on the characteristics of the subject taught, allows you to perform such an important task as to show the internal and external properties of the object, which must be demonstrated in the course of the lesson[5]. This, in turn, shows that it is possible to create multimedia electronic textbooks based on information and pedagogical technologies.

Multimedia tools of information technology are the organization of differential and individual learning process in the learning process, assessment of the learning process, feedback, self-monitoring and correction, demonstration of the studied disciplines and their dynamic process, animation, graphics, animation, sound in science subjects. the use of computer and information technology is particularly important in its most important aspects, such as providing students with important skills for mastering science. Also, the practical side of multimedia tools paves the way for the implementation of such an important task as their use in the educational process and the creation of a database and animated presentations for the educational process in the future education system.

In the process of multimedia teaching, students will be able to fully teach a specific subject on a computer, edit lectures, improve the method of narration based on the analysis of control results, students will be able to see, hear and reflect on the elements of information technology animation on multimedia.

\section{REFERENCES:}

1.Ministerial forum global dialogue on ict and education innovation - towards sustainable development goal for education (sdg 4) proceedings. 18-19 april 2018 • Moscow • Russian federation. http://ru.ite.unesco/org/publications.

2. Nasirova Sh. N., Maxmudova M.A. The importance of electronic education resources in the effectiveness of the lesson Electronic journal of actual problems of modern science, education and training December 2019-V ISSN 2181-9750, Urganch, № 5, 2019. - S.1-8.

3. Xakimov, M. 2021. Distance study of foreign languages: modern trends and development prospects. Society and Innovation. 2, 8/S (Sep. 2021), 252-257. DOI:https://doi.org/10.47689/21811415-vol2-iss8/S-pp252-257.

4. Тухтасинов , И. and Хакимов , М. 2021. Modern views on the problem of distance and traditional methods of teaching italian language in higher education institutions. Society and Innovation. 2, 2 (Apr. 2021), 111-117. DOI:https://doi.org/10.47689/2181-1415-vol2-iss2-pp111117.

5. Ахмедов, М. and Хожикаримова, Г. 2021. Use of innovative courses of innovative character in increasing the quality of education and efficiency of education. Society and Innovation. 2, 2 (Apr. 2021), 1-7. DOI:https://doi.org/10.47689/2181-1415-vol2-iss2-pp1-7. 